\title{
Impact of ultraviolet $B$ radiation applications on some secondary metabolites in thyme (Thymus vulgaris L.)
}

\section{Impacto de la aplicación de radiación ultravioleta B en algunos metabolitos secundarios de tomillo (Thymus vulgaris L.)}
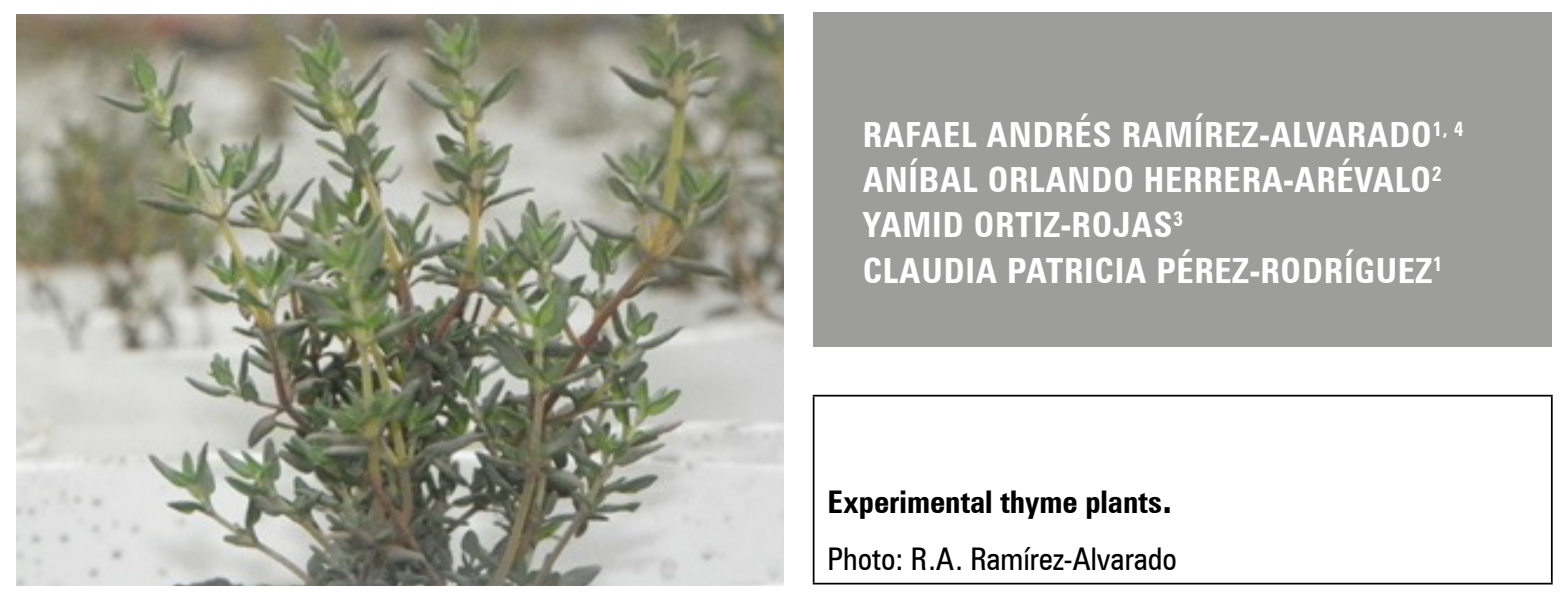

\begin{abstract}
The impact of ultraviolet radiation B (UV-B) applications on the production of secondary metabolites, such as phenols, flavonoids and anthocyanins, in thyme plants was studied. The stems, leaves and flowers were subjected to an experiment design that had a $4 \times 2$ factorial arrangement, evaluating: dose UV-B radiation ( 0.05 and $\left.0.075 \mathrm{Wh} \mathrm{m}^{-2}\right)$, sampling points ( 75 days after transplanting [cut-off point] and 92 days after transplanting [full flowering] according to the $\mathrm{BBCH}$ scale), adaptation time (24 and 49 hours) and extraction matrices of plant material (fresh and dried). The experiment unit corresponded to matrices from Thymus vulgaris L. (C.N. thyme) plants. Ten extractions were done per treatment, and a chemical analysis test were performed in triplicate. The extraction was done with a modified Randall method. The results showed that the application of UV-B radiation at a dose of $0.075 \mathrm{Wh} \mathrm{m}^{-2}$ increased the concentration of secondary metabolites of interest. The compounds that showed a better response to treatment were phenols and anthocyanins.
\end{abstract}

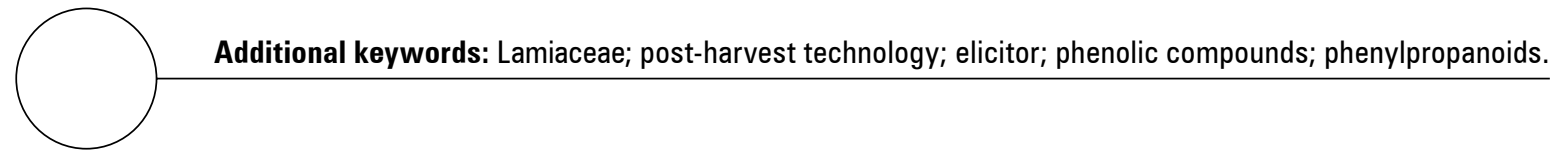

\footnotetext{
Universidad Nacional de Colombia, Faculty of Engineering, Department of Civil and Agricultural Engineering, Bogota (Colombia). ORCID Ramírez-Alvarado, R.A.: 0000-0002-7586-2989; ORCID Peréz-Rodríguez, C.P.: 0000-0002-6131-1887

2 Universidad Nacional de Colombia, Faculty of Agricultural Sciences, Department of Agronomy, Bogota (Colombia). ORCID Herrera-Arévalo, A.O.: 0000-0002-8057-5212

3 Universidad Nacional de Colombia, Faculty of Engineering, Department of Chemical Engineering, Bogota (Colombia). ORCID Ortiz-Rojas, Y.: 0000-0003-4508-0043

4 Corresponding author: rafaela.ramirez@unad.edu.co
} 


\section{RESUMEN}

El impacto de la aplicación de la radiación ultravioleta B (UV-B) en la producción de metabolitos secundarios como fenoles, flavonoides y antocianinas fue estudiado en plantas de tomillo. Los tallos, hojas y flores fueron sometidos a un diseño experimental que consistió en un arreglo factorial $4 \times 2$, evaluando: dosis de radiación UV-B $(0,05$ y 0,075 Wh $\mathrm{m}^{-2}$ ), estado fenológico del momento de muestreo (75 días después del trasplante o fecha de corte o cosecha y 92 días después del trasplante - plena floración), tiempos de adaptación ( 24 y 49 horas) y matrices de extracción del material vegetal (fresco y secado). La unidad experimental correspondió a extractos de matrices frescas y secas de plantas de la especie Thymus vulgaris L. (N.C. tomillo). Se realizaron diez extracciones por tratamiento y las pruebas de análisis químico se realizaron por triplicado. La obtención de los analitos se realizó a través del método Randall modificado. Los resultados indican que la aplicación de radiación UV-B a la dosis de 0.075 Wh $\mathrm{m}^{-2}$ aumenta la concentración de metabolitos secundarios de interés. Los fenoles y antocianinas fueron los compuestos que mostraron una mejor respuesta al tratamiento.

Palabras clave adicionales: Lamiaceae; tecnología poscosecha; inductores; compuestos fenólicos; fenil propanoides.

Received for publication: 02-10-2020 Accepted for publication: 23-11-2020

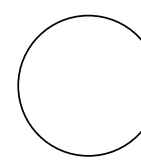

Ultraviolet radiation B (UV-B) has been classified by Gorelick and Bernstein (2014) and other authors as an abiotic-exogenous elicitor. The use of elicitors in the post-harvest stage to improve the quality of fresh fruits and vegetables has been studied in recent decades (Fischer and Pérez, 2012). Some post-harvest treatments investigated for this purpose have been stress by mechanical action, changes in storage temperature, use of ultraviolet radiation, and immersion in solutions of inorganic salts, among others. These post-harvest treatments have gone beyond maintaining the quality of agricultural products to the point of intervening and modifying metabolisms in order to increase or decrease the synthesis of secondary metabolites in plant tissue. This creates an opportunity for innovation through the generation of products and agricultural by-products with added value of interest for the processing industry, as well as for the final consumer, as mentioned by Baenas et al. (2014).

As organisms that depend on solar radiation for the development of many of their biological processes, plants have generated various mechanisms of defense and control against variations in the amount of incident radiation, especially with respect to the incidence of ultraviolet radiation (Hideg et al., 2013). In recent decades, the impact of an increase and change in the distribution of incident ultraviolet radiation on Earth has become a research field of interest, especially in plants of high commercial and medicinal value, such as aromatic plants, as mentioned by Kumari and Prasad (2013). One of the indicators of impact is the presence and concentration of secondary metabolites (alkaloids, glycosides, flavonoids, and tannins, among others).

Some of the various effects caused by stress from ultraviolet $\mathrm{B}$ radiation and reported by Julkunen-Tiitto, Nenadis et al. (2015) are structural changes, alteration in the composition of secondary metabolites, influence on the processes of adaptation and ability to interrupt or inhibit photosynthesis. Another effect of ultraviolet $B$ radiation is the reduction of available oxygen, inducing the generation of free radicals (Kärkönen and Kuchitsu, 2015).

The oxidative stress generated by the incidence of UV B radiation generates a response in plant tissue, expressed as an increase in the biosynthesis of secondary metabolites, such as flavonoids, which have a filtering activity on this type of radiation. This helps to reduce the negative impact of incident radiation on the cell structures of plants, according to Brunetti et al. (2013). Other secondary metabolites, such as phenolic compounds have antioxidant activity. These compounds are the main constituents of the essential oils that can be extracted from aromatic plants, which are a product of interest for these crops. The application of ultraviolet $B$ radiation as a post-harvest treatment can trigger an increase in the 
amount of secondary metabolites that will in turn be reflected in an increase in the quality of extracts and essential oils, increasing the value of these agricultural by-products. Some authors, such as Jenkins (2014), have reported an increase of about $35 \%$ compared to control plants.

The objective of this research was to evaluate the effect of the application of ultraviolet $B$ radiation as a post-harvest technology on the concentration of phytochemical compounds, such as phenols, flavonoids and anthocyanins, present in the ethanolic extracts of Thymus vulgaris $\mathrm{L}$.

\section{MATERIALS AND METHODS}

This test was carried out during the years 2014 to 2016 in the Research Laboratory in Plant Physiology assigned to the Department of Biology of the Universidad Nacional de Colombia, Bogota.

Thymol chemotype thyme cuttings were used, developed in a hydroponic medium. The cuttings were transplanted to a substrate for peat type tests that had a $\mathrm{pH}$ between 5.5 and 6.5 . The plant nutrition management was developed according to the estimation of missing elements and their subsequent complement for optimal performance according to Gómez (2005); Alarcón (2011) and Castro et al. (2013). Irrigation management was carried out by sprinkling according to the parameters established for thyme by Cabot (2003).

The experiment design consisted of a $2 \times 4$ factorial arrangement with the following factors: phenological status of sampling points, radiation dose, time of adaptation to radiation effects and whether the plant material was subjected to drying prior to extraction or not. The experiment unit was the matrices of Thymus vulgaris L. plants (C.N. thyme). Ten extractions were made per treatment, and a chemical analysis test was performed in triplicate.

The stems and leaves of the plants sown in two different phenological stages were taken at 75 and 92 days after transplant (DAT). According to the $\mathrm{BBCH}$ scale, 75 DAT corresponds to the 39G state (nine detectable nodes or cut points), while 92 DAT corresponded to the state of full flowering of the plant (Pérez et al., 2013).
A handmade radiation chamber equipped with Philips TL 40W/12RS lamps (Philips Broadband, Germany) was used to irradiate the samples. According to the technical specifications, the lamps can generate an average dose of $0.045 \mathrm{Wh} \mathrm{m}^{-2}$. The doses were determined based on previous studies carried out on vegetables subjected to this type of radiation by Pérez et al. (2010). To ensure the doses of UV-B radiation, the plant material exposure time to the radiation was used as the measurement criterion. The radiation dose $1,0.05 \mathrm{Wh} \mathrm{m}^{-2}$, was obtained with a time of $1 \mathrm{~h}$ $7 \mathrm{~min}$, and dose $2,0.075 \mathrm{Wh} \mathrm{m}^{-2}$, was obtained with a time of $1 \mathrm{~h} 40 \mathrm{~min}$. The plant material was subjected to radiation and subsequently left in adaptation time. To confirm the effect produced by radiation, part of the vegetal material was not radiated to have a negative control in each of the doses.

The adaptation time was defined as the time necessary for the plant tissue to generate a response to the stimulus, i.e. the application of ultraviolet $\mathrm{B}$ radiation. In this study, 24 and $49 \mathrm{~h}$ were used as the predetermined adaptation time after exposure to radiation doses and compared with the control negative.

\section{Extraction technique and vegetal matrix}

The ethanolic extract for subsequent analyses was obtained by the Randall method with modifications using a SER 148/3 VELP Scientifica device (VELP Scientifica Srl, Usmate Velate MB, Italy). Ethanol was selected as the solvent because of its high polar capacity and broad spectrum of solubilization of phytochemicals. For the extraction process, $1 \mathrm{~kg}$ of fresh or dry irradiated material was taken depending on the case and extraction temperature $(\mathrm{Te})$ of $95^{\circ} \mathrm{C}$, together with an immersion time (I) of $45 \mathrm{~min}$. Afterwards, the extraction thimble was removed from the solvent and left for a wash time (W) of $25 \mathrm{~min}$. Finally, the extraction process ended with a solvent recovery phase of (R) $15 \mathrm{~min}$, according to the methodology reported by Pérez et al. (2013).

Since a drying process can influence the concentration of phytochemicals in a material that is extracted, this effect was studied with extractions in both the fresh matrix and the material subjected to the drying process, using $60 \pm 3^{\circ} \mathrm{C}$ as the drying temperature for $24 \mathrm{~h}$ or until constant weight of the material, according to Sárosi et al. (2013). The drying process was carried out in a Memmert U30 forced convection oven (Memmert GmbH + Co. KG, Germany). 


\section{Quantity of total phenols}

The Folin-Ciocalteu method was used according to the methodology reported by Roby et al. (2013). A sample of the alcoholic extract was taken and placed in a test tube. Then, $10 \mathrm{~mL}$ of saturated sodium carbonate were added with $5 \mathrm{~mL}$ of the Folin-Ciocalteu reagent. The tubes were shaken for $15 \mathrm{~s}$ and placed in a dark place for $30 \mathrm{~min}$. Next, the absorbance of each sample was determined at a wavelength of $760 \mathrm{~nm}$. Gallic acid in solution was used as a standard at different concentrations. The content of total phenols was reported as percentage of gallic acid, using the equation proposed by Roby et al. (2013) (1)

$$
\% A G e M=\frac{E A G}{C e} \times 100
$$

where, \%AGeM corresponds to the percentage of gallic acid in the sample, $E A G$ is the gram equivalent of gallic acid and $\mathrm{Ce}$ is the weight of the extract in $\mathrm{mg}$.

\section{Quantity of total flavonoids}

The total flavonoid content was measured using the methodology from Ghasemi et al. (2014). In a $10 \mathrm{~mL}$ graduated balloon, $2.5 \mathrm{mg}( \pm 0.1 \mathrm{mg})$ of dry extract were placed together with $2 \mathrm{~mL}$ of $80 \%$ ethanol, 200 $\mu \mathrm{L}$ of $10 \%$ aluminum nitrate solution, $200 \mu \mathrm{L}$ of sodium acetate solution and potassium $1 \mathrm{M}$. Finally, the volume was completed with $80 \%$ ethanol. The volumetric balloons were left for $40 \mathrm{~min}$, and the absorbance of the samples was determined at a wavelength of $415 \mathrm{~nm}$. The concentration of flavonoids is usually reported in $\mathrm{mg}$ of quercetin, therefore, a calibration curve of solutions with this pattern was constructed using the following equation (2)

$$
\frac{\mathrm{mgORT}}{\mathrm{mL}}=\frac{\mathrm{A} 415-0.0799}{5.3907}
$$

where, $m g Q R T / m L$ corresponds to $\mathrm{mg}$ of quercetin per $\mathrm{ml}$ of extract and $A 415$ is the absorbance of the sample measured at $415 \mathrm{~nm}$.

\section{Quantity of total anthocyanins}

The content of total anthocyanins in the samples was determined with the $\mathrm{pH}$-differential spectroscopy method following the methodology reported by Medina et al. (2016). $0.5 \mathrm{~g}$ of sample were taken, and $1.0 \mathrm{~mL}$ of water was added, which was agitated for $15 \mathrm{~min}$. Next, the solution was filtered, and two $0.2 \mathrm{~mL}$ samples were taken. The first aliquot was diluted with a buffer solution with $\mathrm{pH} 1.0$, and its absorbance was measured at $530 \mathrm{~nm}$. The other aliquot was diluted in a buffer solution with $\mathrm{pH} 4.5$, and its absorbance was taken at $700 \mathrm{~nm}$. For the calculations, the molar extinction coefficient of the cyanidin-3-glucoside estimated at 26,900 was taken as reference, and the results were expressed in equivalent $\mathrm{mg}$ of glucoside per $100 \mathrm{~g}$ of sample, using the following expression (3)

$$
A m\left(\frac{m g}{100 g}\right)=\frac{\Delta \mathrm{A} \times 449.2 \times \mathrm{FD} \times 100}{26900}
$$

where, Am corresponds to monomeric anthocyanins, $\Delta \mathrm{A}$ is the change in absorbance at the two wavelengths and at the two $\mathrm{pH}$ levels, and $F D$ is the respective dilution factor. The number 26900 is the molar extinction coefficient for cyanidin-3-glucoside at $530 \mathrm{~nm}$, and 100 is the conversion factor of $\mathrm{mg}$ in $100 \mathrm{~g}$ of sample.

All the determinations of chemical parameters (quantity of phenols, flavonoids and anthocyanins) were carried out in triplicate, as well as the measurements in the control samples and the absorbances for all cases. Measurements were taken using a UV-VIS Genesys 5 spectrophotometer (Klab innovative solutions, Seoul, Korea).

\section{RESULTS AND DISCUSSION}

\section{Content of total phenols}

In all cases, the use of UV-B radiation as a post-harvest treatment caused an increase in the total content of phenols with respect to the control samples (Tab. 1). The highest value of total phenols was observed in the plant material from cut plants (75 DAT) subjected to radiation dose $1\left(0.05 \mathrm{Wh} \mathrm{m}^{-2}\right)$, with an adaptation time of $48 \mathrm{~h}$ and plant fresh extraction. It had an increase close to $37.84 \%$ as compared to the control plants. In contrast, the lowest change with respect to the control value $(3.27 \%)$ was obtained in material from the plants in phenological state $92 \mathrm{DAT}$ and subjected to radiation dose $2\left(0.075 \mathrm{Wh} \mathrm{m}^{-2}\right)$, left in adaptation time for $24 \mathrm{~h}$ and extracted from the dried material. The best treatments were those with the highest $\Delta \mathrm{FT}$ : percentage change of treatment as compared to the control. 
Table 1. Content of total phenols in samples of Thymus vulgaris $L$.

\begin{tabular}{|c|c|c|c|c|c|c|}
\hline Sampling points & UV-B dose & $\begin{array}{l}\text { Adaptation time } \\
\text { (h) }\end{array}$ & Plant matrix & $\%$ AGeM & Control & $\begin{array}{l}\Delta F T \\
(\%)\end{array}$ \\
\hline \multirow{8}{*}{$\begin{array}{l}75 \text { DAT } \\
\text { cut point }\end{array}$} & \multirow{2}{*}{1} & 24 & Fresh & $17.85 \pm 059$ & $14.66 \pm 0.45$ & 21.76 \\
\hline & & 48 & Fresh & $17.55 \pm 0.23$ & $14.57 \pm 0.20$ & 20.45 \\
\hline & \multirow{2}{*}{2} & 24 & Fresh & $19.46 \pm 0.26$ & $15.7272 \pm 1.74$ & 23.73 \\
\hline & & 48 & Fresh & $19.48 \pm 0.32$ & $17.44 \pm 0.76$ & 11.70 \\
\hline & \multirow{2}{*}{1} & 24 & Dry & $12.07 \pm 0.42$ & $11.27 \pm 0.07$ & 7.10 \\
\hline & & 48 & Dry & $15.81 \pm 0.50$ & $11.47 \pm 2.06$ & 37.84 \\
\hline & \multirow{2}{*}{2} & 24 & Dry & $14.03 \pm 0.95$ & $11.31 \pm 0.45$ & 24.05 \\
\hline & & 48 & Dry & $13.62 \pm 1.48$ & $11.41 \pm 1.77$ & 19.37 \\
\hline \multirow{8}{*}{$\begin{array}{l}92 \text { DAT } \\
\text { full bloom }\end{array}$} & \multirow{2}{*}{1} & 24 & Fresh & $16.25 \pm 0.21$ & $14.61 \pm 0.51$ & 11.23 \\
\hline & & 48 & Fresh & $17.04 \pm 0.56$ & $13.85 \pm 2.05$ & 23.03 \\
\hline & \multirow{2}{*}{2} & 24 & Fresh & $19.57 \pm 0.09$ & $14.42 \pm 0.17$ & 35.71 \\
\hline & & 48 & Fresh & $19.38 \pm 0.20$ & $14,48 \pm 1.92$ & 33.84 \\
\hline & \multirow{2}{*}{1} & 24 & Dry & $11.23 \pm 0.91$ & $10.19 \pm 0.32$ & 10.21 \\
\hline & & 48 & Dry & $12.16 \pm 1.03$ & $10.61 \pm 0.65$ & 14.61 \\
\hline & \multirow{2}{*}{2} & 24 & Dry & $11.38 \pm 1.61$ & $11.02 \pm 0.86$ & 3.27 \\
\hline & & 48 & Dry & $12.38 \pm 0.61$ & $10.82 \pm 0.55$ & 14.42 \\
\hline
\end{tabular}

DAT: days after transplantation. UV-B radiation, dose $1=0.05 \mathrm{Wh} \mathrm{m}^{-2}$ and dose $2=0.075 \mathrm{Wh} \mathrm{m}^{-2}$. \%AGeM: percentage of gallic acid in the sample. $\Delta \mathrm{FT}$ : percentage change of treatment regarding control.

At the statistical level, there were no significant differences; however, the drying process had a direct negative effect on the amount of phenols present in the alcohol extracts subsequently obtained. This may have been due to the thermolabile characteristic of the phenolic compounds.

The results were similar to those reported in the literature for various genres. The increase in the concentration of this class of compounds, especially thymol and carvacrol, have been reported by Inostroza-Blancheteau et al. (2014).

\section{Total flavonoids}

In the case of total flavonoid content, the material from the plants with $92 \mathrm{DAT}$, subjected to radiation dose 2, left for $48 \mathrm{~h}$ at adaptation time and extracted from the fresh material, showed an increase of $80 \%$ with respect to the control plant and was the best among all combinations of treatments. In contrast, results with a lower increase were obtained in plants at the cut-off point (75 DAT), with a low radiation dose $\left(0.05 \mathrm{Wh} \mathrm{m}^{-2}\right)$ and at both adaptation times $(24$ and $48 \mathrm{~h}$ ), with increases of 10.96 and $14.08 \%$, respectively (Tab. 2). The best treatments are those with the highest $\triangle$ FLT: percentage change of treatment as compared to the control.
The impact on the production of flavonoids in plant tissues subjected to ultraviolet radiation has been studied through the effect that this kind of radiation has on various metabolic pathways of plants. Ultraviolet radiation has been found to stimulate specific enzymes such as phenylalanine ammonia lyase (PAL), chalcone synthase (CHS) and chalcone isomerase (CHI). The stimulation of the previous enzymes has a direct effect on the production of secondary metabolites, especially flavonoids. Jenkins (2014) reported that the effect has been observed to be greater if the plant material is subjected to moderate doses of UV radiation, especially in the $B$ range.

\section{Content of total anthocyanins}

The number of total anthocyanins quantified in the study was stimulated with the application of the treatments. The material from plants in phenological stage of 92 DAT, submitted to the highest radiation dose used in the study $\left(0.075 \mathrm{Wh} \mathrm{m}^{-2}\right)$ and left in both adaptation times (48 and $24 \mathrm{~h}$ ), showed a greater increase in the amount of anthocyanins. This plant material had increases of $77.39 \%$ and $61.33 \%$ with respect to the value obtained with the control plant material, as shown in table 3 . The best treatments had the highest $\Delta \mathrm{A}$ : percentage change of treatment as compared to the control. 
Table 2. Total flavonoid content of thyme samples.

\begin{tabular}{|c|c|c|c|c|c|c|}
\hline Sampling points & UV-B dose & $\begin{array}{l}\text { Adaptation time } \\
\text { (h) }\end{array}$ & Plant matrix & $\mathrm{mg} \mathrm{ORT/g}$ & Control & $\begin{array}{c}\triangle \mathrm{FLT} \\
(\%)\end{array}$ \\
\hline \multirow{8}{*}{$\begin{array}{l}75 \text { DAT } \\
\text { cut point }\end{array}$} & \multirow{2}{*}{1} & 24 & Fresh & $0.081 \pm 0.001$ & $0.073 \pm 0.003$ & 10.96 \\
\hline & & 48 & Fresh & $0.081 \pm 0.001$ & $0.071 \pm 0.003$ & 14.08 \\
\hline & \multirow{2}{*}{2} & 24 & Fresh & $0.104 \pm 0.001$ & $0.075 \pm 0.001$ & 38.67 \\
\hline & & 48 & Fresh & $0.114 \pm 0.002$ & $0.075 \pm 0.001$ & 52 \\
\hline & \multirow{2}{*}{1} & 24 & Dry & $0.047 \pm 0.003$ & $0.036 \pm 0.002$ & 30.56 \\
\hline & & 48 & Dry & $0.045 \pm 0.001$ & $0.035 \pm 0.001$ & 28.57 \\
\hline & \multirow{2}{*}{2} & 24 & Dry & $0.057 \pm 0.001$ & $0.039 \pm 0.001$ & 46.15 \\
\hline & & 48 & Dry & $0.056 \pm 0.002$ & $0.039 \pm 0.001$ & 43.59 \\
\hline \multirow{8}{*}{$\begin{array}{c}92 \text { DAT } \\
\text { full bloom }\end{array}$} & \multirow{2}{*}{1} & 24 & Fresh & $0.075 \pm 0.002$ & $0.061 \pm 0.001$ & 22.95 \\
\hline & & 48 & Fresh & $0.075 \pm 0.003$ & $0.062 \pm 0.001$ & 20.97 \\
\hline & \multirow{2}{*}{2} & 24 & Fresh & $0.092 \pm 0.001$ & $0.057 \pm 0.001$ & 61.4 \\
\hline & & 48 & Fresh & $0.099 \pm 0.002$ & $0.055 \pm 0.002$ & 80.00 \\
\hline & \multirow{2}{*}{1} & 24 & Dry & $0.040 \pm 0.002$ & $0.028 \pm 0.001$ & 42.86 \\
\hline & & 48 & Dry & $0.040 \pm 0.001$ & $0.028 \pm 0.001$ & 42.85 \\
\hline & \multirow{2}{*}{2} & 24 & Dry & $0.050 \pm 0.002$ & $0.035 \pm 0.002$ & 42.86 \\
\hline & & 48 & Dry & $0.050 \pm 0.002$ & $0.035 \pm 0.001$ & 42.85 \\
\hline
\end{tabular}

DAT: days after transplantation. UV-B radiation, dose $1=0.05 \mathrm{Wh} \mathrm{m}^{-2}$ and dose $2=0.075 \mathrm{Wh} \mathrm{m} \mathrm{m}^{-2} . \mathrm{mg}$ ORT/g: $\mathrm{mg}$ of quercetin per g of sample. $\Delta \mathrm{FLT}$ : percentage change of treatment regarding control.

Table 3. Anthocyanin content of thyme samples

\begin{tabular}{|c|c|c|c|c|c|c|}
\hline Sampling points & UV-B dose & $\begin{array}{l}\text { Adaptation time } \\
\text { (h) }\end{array}$ & Plant Matrix & $\mathrm{mgC3G}$ & Control & $\triangle \mathrm{A}$ \\
\hline \multirow{8}{*}{$\begin{array}{c}75 \text { DAT } \\
\text { cut point }\end{array}$} & \multirow{2}{*}{1} & 24 & Fresh & $14.27 \pm 1.32$ & $12.16 \pm 1.53$ & 17.35 \\
\hline & & 48 & Fresh & $14.42 \pm 0.91$ & $12.18 \pm 0.85$ & 18.39 \\
\hline & \multirow{2}{*}{2} & 24 & Fresh & $17.65 \pm 0.34$ & $12.80 \pm 0.88$ & 37.89 \\
\hline & & 48 & Fresh & $18.43 \pm 0.14$ & $12.89 \pm 0.36$ & 42.98 \\
\hline & \multirow{2}{*}{1} & 24 & Dry & $0.15 \pm 0.10$ & $0.09 \pm 0.00$ & NA \\
\hline & & 48 & Dry & $0.27 \pm 0.09$ & $0.16 \pm 0.10$ & NA \\
\hline & \multirow{2}{*}{2} & 24 & Dry & $0.18 \pm 0.00$ & $0.00 \pm 0.05$ & NA \\
\hline & & 48 & Dry & $0.00 \pm 0.00$ & $0.09 \pm 0.09$ & NA \\
\hline \multirow{8}{*}{$\begin{array}{c}92 \text { DAT } \\
\text { full bloom }\end{array}$} & \multirow{2}{*}{1} & 24 & Fresh & $17.11 \pm 1.37$ & $13.10 \pm 0.24$ & 30.61 \\
\hline & & 48 & Fresh & $17.44 \pm 1.14$ & $13.22 \pm 0.77$ & 31.92 \\
\hline & \multirow{2}{*}{2} & 24 & Fresh & $28.33 \pm 1.17$ & $17.56 \pm 0.19$ & 61.33 \\
\hline & & 48 & Fresh & $30.99 \pm 1.35$ & $17.47 \pm 0.61$ & 77.39 \\
\hline & \multirow{2}{*}{1} & 24 & Dry & $0.18 \pm 0.09$ & $0.15 \pm 0.05$ & NA \\
\hline & & 48 & Dry & $0.09 \pm 0.15$ & $0.06 \pm 0.10$ & NA \\
\hline & \multirow{2}{*}{2} & 24 & Dry & $0.09 \pm 0.09$ & $0.07 \pm 0.05$ & NA \\
\hline & & 48 & Dry & $0.06 \pm 0.05$ & $0.00 \pm 0.00$ & NA \\
\hline
\end{tabular}

DAT: days after transplantation. UV-B radiation, dose $1=0.05 \mathrm{Wh} \mathrm{m}^{-2}$ and dose $2=0.075 \mathrm{Wh} \mathrm{m}^{-2}$. $\mathrm{mgC3G} \mathrm{mg}$ of cyanidin-3-glucoside. $\triangle \mathrm{A}$ : percentage change of treatment regarding control. NA: It does not apply because of degradation in the drying process. 
These results can be explained by the metabolic pathways elucidated for plants (Tholl, 2015) and confirm that the synthetic routes of acetate-malonate and shikimic acid are stimulated with the use of UV-B radiation as a post-harvest treatment. This occurs because routes are responsible for the specific production of phenols. As shown in table 3, the concentration of anthocyanins was higher in the extracts obtained from the fresh irradiated material because of the low thermal stability exhibited by anthocyanins, which are degraded in the drying process.

In a study by Cechin et al. (2012), passion fruit plants were subjected to high doses of UV-B radiation (about $8 \mathrm{~W} \mathrm{~m}^{-2}$ ), and the amount of anthocyanins present was measured. Their results showed an increase with respect to their control values and coincided with the results obtained with Thymus vulgaris L. This demonstrates that the generation of this class of compound constitutes a natural defense method against a change in radiation perceived by the plant material.

In a recent study conducted by Huyskens-Keil et al. (2020), post-harvest white asparagus with different sources of light and UV-C radiation showed that the application of UV-C radiation stimulates the enzymatic action of phenylalanine ammonia-lyase [PAL, EC 4.3.1.5] and guaiacol peroxidase [POD, EC 1.11.1.7]. This is reflected in a decrease in the concentration of anthocyanins in plant tissues. The authors stated that the use of different sources of light radiation affects the post-harvest metabolism of this product differently, even stimulating the production of anthocyanins.

The relationship between anthocyanin synthesis and UV-B radiation was recently studied by $\mathrm{Hu}$ et al. (2020) in research on the expression of the transcription factor MdWRKY72 in apples, which is one of the factors attributed to the regulation of anthocyanin biosynthesis. The present study sought to elucidate some of the mechanisms of gene transcription that was stimulated by UV-B radiation applications, which decisively influenced the production of anthocyanins. This provides tools for the total elucidation of the underlying synthesis of anthocyanins induced by UV-B mediated by MdWRKY72.

\section{CONCLUSIONS}

The moderate doses of ultraviolet $B$ radiation were an excellent promoter of phenolic compounds, flavonoids and anthocyanins in the thyme plants. These components increased their production thanks to the physical, external abiotic capacity of the ultraviolet $B$ radiation. When mediated by adaptation times and phenological timing of applications, this radiation can obtain substances with nutraceutical and pharmacological uses, providing a potential technique for the non-invasive improvement of plants.

\section{ACKNOWLEDGMENTS}

The authors thank Professor Luz Marina Melgarejo Muñoz from the Department of Biology of the Universidad Nacional de Colombia and Professor Oscar Eduardo Suarez Moreno, of the Universidad Nacional Abierta y a Distancia (UNAD).

Conflict of interests: The manuscript was prepared and reviewed with the participation of the authors, who declare that there exists no conflict of interest that puts at risk the validity of the presented results.

\section{BIBLIOGRAPHIC REFERENCES}

Alarcón, J. 2011. Plantas aromáticas y medicinales - Enfermedades de importancia y sus usos terapéuticos - Medidas para la temporada invernal. ICA, Bogota, DC.

Baenas, N., C. García-Viguera, and D.A. Moreno. 2014. Elicitation: a tool for enriching the bioactive composition of foods. Molecules 19(9), 13541-13563. Doi: 10.3390/molecules190913541

Brunetti, C., M. Di Ferdinando, A. Fini, S. Pollastri, and M. Tattini. 2013. Flavonoids as antioxidants and developmental regulators: relative significance in plants and humans. Int. J. Mol. 14(2), 3540-3555. Doi: 10.3390/ ijms14023540

Cabot, P. 2003. Estudio de multiplicación, requerimientos hídricos y de fertilización de diferentes especies aromáticas y medicinales de interés comercial actual. Centro de Cabrils, IRTA, Spain.

Castro, D., J. Díaz, R. Serna, M. Martínez, P. Urrea P., K. Muñoz, and E. Osorio. 2013. Cultivo y producción de plantas aromáticas y medicinales. Universidad Católica de Oriente (UCO), Medellin, Colombia.

Cechin, I., V. Rocha, and T. Fumis. 2012. Sensitivity of yellow passion fruit to ultraviolet-B radiation. Pesq. Agropec. Bras. 47(10), 1422-1427. Doi: 10.1590/ S0100-204X2012001000002

Fischer, G. and C.P. Pérez. 2012. Efecto de la radiación solar en la calidad de los productos hortícolas. In: Proc. Congreso Internacional de Hortalizas en el Trópico. Bogota, 28-30 Nov. 2012. Sociedad Colombiana de Ciencias Hortícolas, Bogota. 
Ghasemi, A., A. Siahpoosh, M. Setayesh, and L. Craker. 2014. Antioxidant activity, total phenolic and flavonoid contents of some medicinal and aromatic plants used as herbal teas and condiments in Iran. J. Med. Food. 17(10), 1151-1157. Doi: 10.1089/jmf.2013.0057

Gómez, M.I. 2005. Guía técnica para el manejo nutricional de los cultivos: Diagnostico, interpretación y recomendación de planes de fertilización. Microfertisa, Bogota, DC.

Gorelick, J. and N. Bernstein. 2014. Elicitation: an underutilized tool for the development of medicinal plants as a source for therapeutic secondary metabolites. Adv. Agron. 124, 201-230. Doi: 10.1016/ B978-0-12-800138-7.00005-X

Hideg, É., M.A. Jansen, and A. Strid. 2013. UV-B exposure, ROS, and stress: inseparable companions or loosely linked associates? Trends Plant Sci. 18(2), 107-115. Doi: 10.1016/j.tplants.2012.09.003

Hu, J., H. Fang, J. Wang, X. Yue, M. Su, Z. Mao, Q. Zou, H. Jiang, Z. Guo, L. Yu, T. Feng, L. Lu, Z. Peng, Z. Zhang, N. Wang, and X. Chen. 2020. Ultraviolet B-induced MdWRKY72 expression promotes anthocyanin synthesis in apple. Plant Sci. J. 292, 110377. Doi: 10.1016/j.plantsci.2019.110377

Huyskens-Keil, S., I. Eichholz-Dündar, K. Hassenberg, and W.B. Herppich. 2020. Impact of light quality (white, red, blue light and UV-C irradiation) on changes in anthocyanin content and dynamics of PAL and POD activities in apical and basal spear sections of white asparagus after harvest. Postharvest Biol. Technol. 161, 111069. Doi: 10.1016/j.postharvbio.2019.111069

Inostroza-Blancheteau, C., M. Reyes-Díaz, A. Arellano, M. Latsague, P. Acevedo, R. Loyola, P. Arce-Johnson, and M. Alberdi. 2014. Effects of UV-B radiation on anatomical characteristics, phenolic compounds and gene expression of the phenylpropanoid pathway in highbush blueberry leaves. Plant Physiol. Biochem. 85, 8595. Doi: 10.1016/j.plaphy.2014.10.015

Jenkins, G.I. 2014. The UV-B photoreceptor UVR8: from structure to physiology. Plant Cell Rep. 26(1), 21-37. Doi: 10.1105/tpc.113.119446

Julkunen-Tiitto, R., N. Nenadis, S. Neugart, M. Robson, G. Agati, J. Vepsäläinen, G. Zipoli, L. Nybakken, B. Winkler, and M.A.K. Jansen. 2015. Assessing the response of plant flavonoids to UV radiation: an overview of appropriate techniques. Phytochem. Rev. 14(2), 273-297. Doi: 10.1007/s11101-014-9362-4
Kärkönen, A. and K. Kuchitsu. 2015. Reactive oxygen species in cell wall metabolism and development in plants. Phytochemistry 112, 22-32. Doi: 10.1016/j. phytochem.2014.09.016

Kumari, R. and M.N.V. Prasad. 2013. Medicinal plant active compounds produced by UV-B exposure. J. Sustain. Agr. 225-254. Doi: 10.1007/978-94-007-5961-9_8

Medina, L. 2016. Evaluación en el rendimiento de las extracciones variando $\mathrm{pH}$ y cuantificación de antocianinas totales por el método de $\mathrm{pH}$ diferencial en el extracto etanolico Vaccinium myrtillus "Arándano". Undergraduate thesis. Universidad Nacional de Trujillo, Trujillo, Peru.

Pérez, C.P., A. Herrera, and R. Ramírez. 2013. Efecto de la aplicación de elicitores físicos durante la poscosecha en aceites esenciales de menta y romero. pp. 19081913. In: VII Congreso Ibérico de Agroingenieria y Ciencias Hortícolas. Madrid.

Pérez, C.P., C. Ulrichs, and S. Huyskens-Keil. 2010. Physiologische Veränderungen in Früchten der Solanace Engewächse in Abhängigkeit von physikalischen Elicitoren während der Produktion und nach der Ernte. Humboldt-Universität zu Berlin, Berlin.

Roby, M.H.H., M.A. Sarhan, K.A. Selim, and K.I. Khalel. 2013. Evaluation of antioxidant activity, total phenols and phenolic compounds in thyme (Thymus vulgaris L.), sage (Salvia officinalis L.), and marjoram (Origanum majorana L.) extracts. Ind. Crops Prod. 43, 827-831. Doi: $10.1016 /$ j.indcrop.2012.08.029

Sárosi, S., L. Sipos, Z. Kókai, Z. Pluhár, B. Szilvássy, and I. Nováka. 2013. Effect of different drying techniques on the aroma profile of Thymus vulgaris analyzed by GCMS and sensory profile methods. Ind. Crops Prod. 46, 210-216. Doi: 10.1016/j.indcrop.2013.01.028

Shayganfar, A., M. Azizi, and M. Rasouli. 2018. Various strategies elicited and modulated by elevated UV-B radiation and protectant compounds in thymus species: differences in response over treatments, acclimation and interaction. Ind. Crops Prod. 113, 298-307. Doi: 10.1016/j.indcrop.2018.01.056

Tholl, D. 2015. Biosynthesis and biological functions of terpenoids in plants. pp. 63-106. In: Schrader, J. and J. Bohlmann (eds.). Biotechnology of isoprenoids. Springer International Publishing, Cham, Switzerland. Doi: 10.1007/10_2014_295 